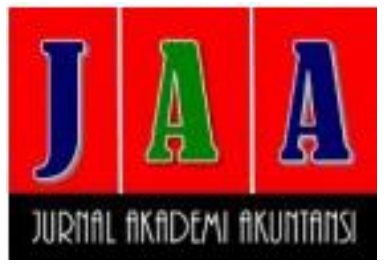

\title{
INTELLECTUAL CAPITAL DISCLOSURE (ICD): A COMPARISON BETWEEN INDONESIAN AND CHINESE UNIVERSITIES
}

\author{
Aviani Widyastuti *, Siska Aprillia \\ Program Studi Akuntansi, Fakultas Ekonomi dan Bisnis \\ Universitas Muhammadiyah Malang \\ Jl. Raya Tlogomas No. 246 Malang \\ *Corresponding author :aviani@umm.ac.id
}

\begin{abstract}
The purpose of this study was to identify the practice of disclosure of information on intellectual capital on the website of the university in Indonesia and China. This research uses website the 10 best universities in Indonesia and China (version 4ICU survey 2018) as an object of study. Intellectual capital components used in this study is a framework developed by Leitner (2004) which consists of 36 items: 10 items of human capital, structural capital of 11 items, and 15 items of relational capital. The analysis used is content analysis, the different test performed using the Mann-Whitney test in SPSS. The results showed that there was no difference between the best universities in Indonesia and China to disclose information on intellectual capital through their website. In general, the number of IC disclosures through the best universities in Indonesia and China was around $45 \%$, the rest is not disclosed.
\end{abstract}

Keywords: Index, Intellectual Capital Disclosure, University, 4ICU

JEL Classification : E44, G23

Diterima : 08 Oktober 2019

Direview : 09 Oktober 2019

Direvisi : 07 November 2019

Diterima : 22 November 2019

Artikel ini tersedia di website :

http://ejournal.umm.ac.i d/index.php/jaa

\section{INTRODUCTION}

Intellectual capital becomes an issue for the wider community, research centers and even through college (Childs 2011). The term became popular when the intellectual capital Steward (1997) write about Brainpower in Fortune magazine. Knowledge, innovation and intellectual capital in a university into a separate mechanism for countries that aims to build a sustainable competitive advantage (Chen and Chen 2018). The higher education system in China at first mimic the European system is very formal and rigid. Submission of subjects without being offered questioning or interaction between faculty and students (Bonavia 1999). The students who go to college based on party leaders to provide opportunities for young people whose background "social revolutionary" in college, namely the workers, poor peasants and lower middle peasants (Bonavia 1999),

Orleans (1960) identifies five types of higher education institutions in China before the cultural revolution. First, a comprehensive college is equivalent to college in the US with a 4-year study period. Second, polytechnic institutes, such as Qinghua University in Beijing. The third mode until the fifth developed during and after the 
Great Leap, the Higher Education specialization organized in vocational, college parttime controlled companies for their employees, and colleges for workers and peasants of low quality. China is developing rapidly in the fields of education. The Chinese government is targeting 500.000 students enroll in Chinese universities in 2020 (Tung 2001). These numbers show the extent to which the strategy has been made by the Chinese government in improving the performance of universities in the country, and encourage students from abroad to study in China. According to Tung (2001), the Chinese government also improve facilities, build research centers, attract educated students and faculty from around the world with more progress being made.

Universities in Indonesia to expand the realization issuance Indonesian Government Regulation Number 24 of 1997 and Indonesian Government Regulation Number 43 of 2008 . To the new era of Indonesian universities, have developed very rapidly (Sugianto and Trilaksana 2015). University is an institution that has a role and strategic position in the achievement of educational goals at the macro and the need to make improvements on an ongoing basis to realize quality human resources. Human existence as a very important resource in a university for the human resources able to support through the work, talent, creativity, drive, and a real role. Universities can not move forward without the human element in it (Sugianto and Trilaksana 2015). The most important investment in university contained in the research sector and human resources (Canibano and Sanchez 2009). Associated with the university's primary function is the production and dissemination of knowledge, universities need to improve competitiveness and service, and report to stakeholders what had happened to the university from the standpoint of the development of knowledge and contribute to the transparency and increase trust (Constantin 2005). Heavy competition is getting tougher and the university, the university seeks to improve and develop by evaluating intellectual capital in universities (Constantin 2007),

Research on the intellectual capital disclosure (ICD) is rarely done at universities, these studies have tended more done in the company. So that researchers interested conducting research on the public sector, namely the university, where the object of this research is the best university in Indonesia and China to develop a model framework (framework) reporting of intellectual capital (intellectual capital disclosure ICD) at state universities in Indonesia and China.This research a comparative intellectual capital disclosure (ICD) between the best Indonesian 10 universities and 10 the best Chinese universities according to the survey 4 International Colleges And Universities (4ICU), where 4ICU is an international website search engine that analyzed the 13,600 university website in the world spread over 200 countries, and then stratified by category respectively. 4ICU has been selected for visible data required. As 4ICU, this study also relied on secondary data published on the official website of each university. This is done because the best universities in Indonesia and China always do the developments of the website and has great potential in producing graduates that ICR would be better. This study uses the components of intellectual capital disclosure (ICD) which is owned by the university (Leitner 2004). 


\section{THEORETICAL STUDIES}

This study used a stakeholder theory approach. Stakeholder theory further considers stakeholder positions are considered powerful. This is because the stakeholders concerned to influence the management in the process of exploiting the full potential of the organization, because only with good management and a maximum over the whole potential of this organization will be able to create value added to later encourage the company's financial performance which is an orientation of the stakeholders in intervening in the management, This group was a major consideration for companies to disclose some information in the annual report of the company. Intellectual Capital Disclosures required for stakeholders.

\section{Intellectual capital}

The concept of intellectual capital has been defined and confirmed by the strong for the first time by Steward (1997) one of the famous magazine editors in America (Pribac 2010). Three categories of IC (Bontis 1998; Bjurstrom and Roberts 2007) generally accepted, that relational capital, which refers to the organization's external network; human capital, which identifies the knowledge, skills, experience, and capabilities of each employee; and organizational capital (or structural), which includes procedures, systems, and other organizational forms (especially) codified knowledge. Another approach, which is dynamic, has evolved from a different conception of the company (Marzo 2014). According to Constantin (2007), intellectual capital arises because of the significant differences between the recognition of book value and the market value of the company. In recent years, efforts intensified research indicates the importance of the domain, but also the difficulty of expressing intangible. Although, in the last decade, knowledge management and intellectual capital especially in the context of private companies, there is an increased interest in public organizations, such as universities and research centers. This is mainly due to the fact that the university has the primary objective in the production and dissemination of knowledge (Sanchez et al. 2006). Intellectual Capital (IC) has been defined as a combination of intangible resources and activities that "allows an organization to transform a material, financial and human resources in a system that is capable of creating stakeholder value (Robert 1999).

Intellectual Capital is the combination of human resources, relational, and activities of the organization's activities. First, Human Capital is defined as the knowledge that human resources (teachers, researchers, Ph.D. students, and administrative staff) will take them if they leave the institution. Second, the Organization Capital is defined as the knowledge that is in the institution at the end of the working day. It consists of the principles of governance, organizational routines, procedures, systems, cultures, databases, publications, intellectual property, etc. Lastly, Relational Capital is defined as all resources associated with the external relations agencies such as the "customer", "supplier", R \& D partners, government, etc (Sanchez et al. 2006). 


\section{Intellectual capital disclosure/in universities}

The concept of Disclosure IC for university-based largely on the experience and methods developed in the industry/company. IC reporting idea was born in the Nordic countries in the early nineties. Swedish insurance company published the first IC reports in 1992 as a supplement to its annual report (Leitner 2002). The University is a scientific institution with a good core activity of the creation of knowledge through scientific research, increase knowledge through counseling, or learn and share through education (Najim et al. 2012). The University is an excellent example of a model that generates new knowledge, experience, and knowledge dissemination and distribution of books, studies, and documentation. Universities play a role similar to that played factories in the industrial revolution, and the ideas and new experience in which plays the same role with the new equipment that is played in the traditional economy. In this context, we need to realize the importance of the university and the role it plays in supporting the intellectual capital (Najim et al. 2012). Instruments reports IC and common methods for assessing intangibles in university find the justification of one side of the political challenges and managerial requires the implementation of management systems and new reporting to improve the internal management IC and for disclosing information to the stakeholders, from the other side in consideration that national and supranational organisms recognize the central role of universities in a knowledge-based society that is actually (Commission Europe 2006). In addition, the university is a producer of knowledge of their most important output is knowledge incorporated in the results of research, publications and students educated (Sanchez et al. 2006). Reduce IC category in the university context, human capital is the knowledge of researchers and nonscientific staff of the university as professors, researchers, Ph.D. students, and administrative staff; structural capital consists of principles and modes of governance, organizational routines and procedures, cultural systems, databases, and intellectual property; relational capital can be assimilated into what is called the third mission of the university, which includes all activities and relationships between university and nonacademic partners, namely, corporations, nonprofit organizations, public authorities, local governments, and society as a whole (Leitner 2004; Sanchez et al. 2009). Universities must evaluate intellectual capital are enhanced transparency; Intellectual capital reports that allow comparing different ranking systems of other universities; strengthen the relationship between universities and the business environment with the same language (Suciu et al. 2011).

\section{METHODOLOGY}

\section{Research Method}

This research is a comparative study, the research compares two or more objects you are in a topic/field (Ulum and Juanda 2016). The object of this study is 10 (ten) best university version 4 International Colleges and Universities (4 ICU) in 2018 in Indonesia and China. The data used in this research is secondary data, which is a source of research data obtained by researchers indirectly through an intermediary medium (Supomo and Indriantoro 2002). This data is obtained from official websites of each 
university with the observation period between the date of August 18, 2018, until 18 September 2018.

Intellectual Capital Framework Disclosure (ICD) used is the Intellectual Capital Disclosure framework for the university consists of 36 items which are components of Intellectual Capital owned Leitner (2004). Here are 36 items Intellectual Capital used in this study:

Table 1. Items Disclosure of Intellectual Capital

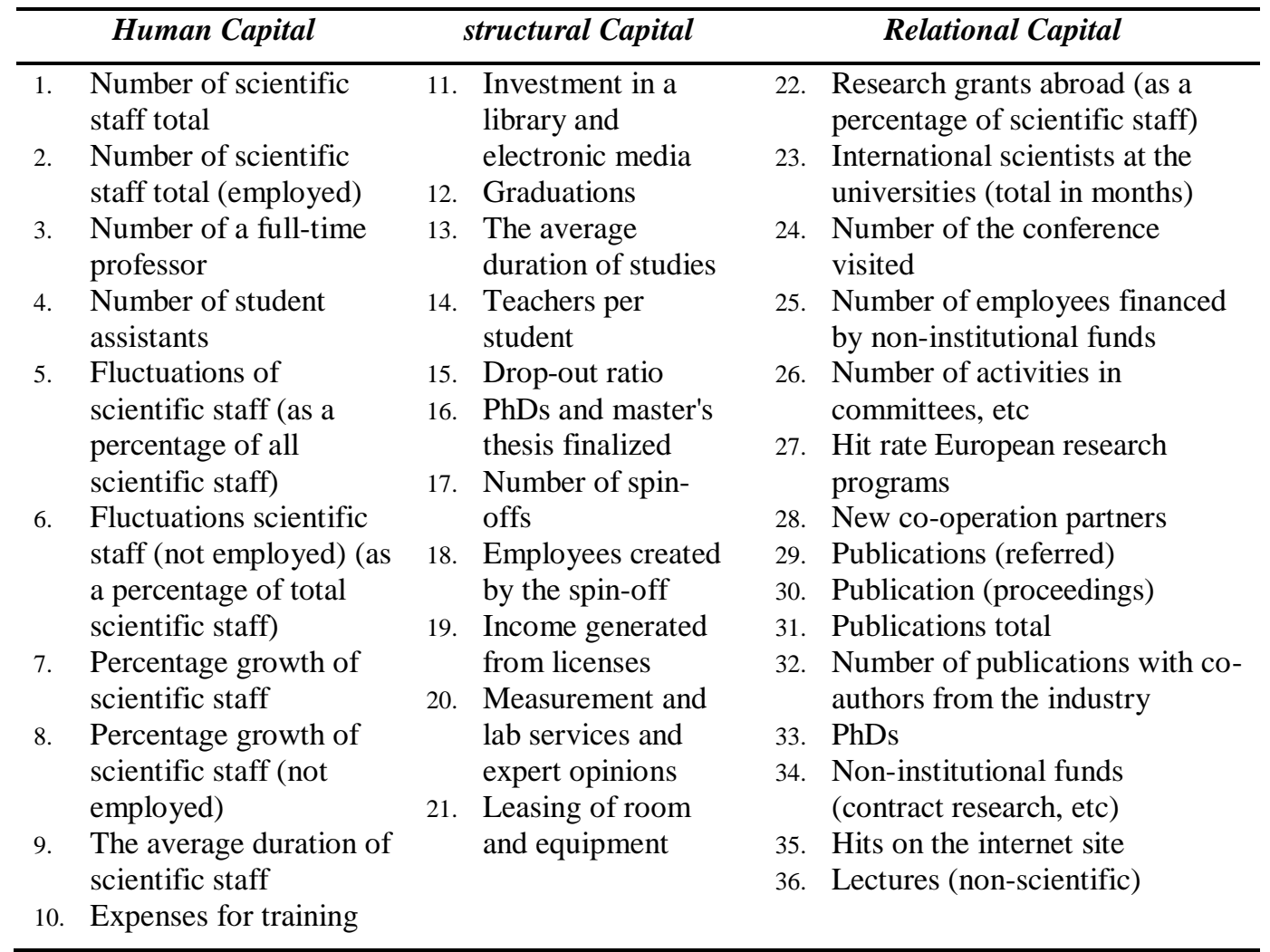

Source: Leitner (2004)

\section{Research Analytics}

Research analytics determines the content of the second stage, in which a determination of two components of the assessment procedure is made. Data analysis was performed in two stages: first, content analysis. This analysis is done by providing a checklist of the items IC disclosed in the official website of each university. After the checklist, the next stage does the summation of the items disclosed in each of the universities. Disclosure of information IC approach five ways numerical coding system to provide appropriate criteria for projection using a numeric code, in this approach the criteria used are:

$0 \quad$ : IC information item not disclosed

1 : IC information items disclosed in a narrative form

2 : IC information items disclosed in a numeric form

3 : IC information items disclosed in the form of monetary value

4 : IC information items disclosed in the form of images/graphics 
Second analysis, Mann-Whitney test is one of the non-parametric tests were very strong and is an alternative test of parametric test t-test (Ghozali 2006). Steps Mann-Whitney test by comparing the number of items disclosed IC among the best universities in Indonesia and the best universities in China. The beginning of Human Capital, Structural Capital, and Relational Capital.

\section{RESULTS}

\section{Descriptive Statistics}

This study was conducted on 18 August to 18 September 2018. The object of research using a sample of 10 best universities version 4 International Colleges and Universities (4 ICU) of 2018 in Indonesia and China.

The first analysis was conducted a content analysis. This analysis is used to identify the item IC disclosed in the official website of the university in Indonesia and China. This analysis is done by giving a checklist. Giving checklist performed on the items disclosed in the official website of the university. The bases used to give a value of "O" if the item is not disclosed, the value of " 1 " if the item is expressed in narrative form, a " 2 " if the item is expressed in numerical form, the value of " 3 " if the item is expressed in monetary value, and value " 4 "if the item is expressed in the form of pictures/graphics.

Table 2 presents the descriptive statistics information of associated components of IC such as Human Capital, Structural Capital, and Relational Capital. Disclosure of information Intellectual Capital approach five ways numerical coding system by giving the index as the table is not Disclosed, Disclosed narrative, numeric Disclosed, Disclosed currency, and graphics Disclosed.

Table 2. Descriptive Statistics

\begin{tabular}{llllllll}
\hline & $\mathrm{N}$ & $\begin{array}{l}\text { Mini } \\
\text { mum }\end{array}$ & $\begin{array}{l}\text { Maxi } \\
\text { mum }\end{array}$ & Sum & mean & $\begin{array}{l}\text { Std. } \\
\text { deviation }\end{array}$ & variance \\
\hline Indonesia & & & & & & & \\
Index & 10 & 33.33 & 66.67 & 533.33 & 53.3333 & 12.61436 & 159122 \\
Not_Disclosed & 10 & $12: 00$ & 24.00 & 168.00 & 16.8000 & 4.54117 & 20622 \\
Narrative_Disc & 10 & $9: 00$ & $19: 00$ & 133.00 & 13.3000 & 2.62679 & 6,900 \\
Numeric_Disc & 10 & .00 & $9: 00$ & 43.00 & 4.3000 & 3.65300 & 13344 \\
Currency_Disc & 10 & .00 & .00 & .00 & .0000 & .00000 & .000 \\
& & & & & & & \\
Graphics_Disc & 10 & .00 & $6: 00$ & $16: 00$ & 1.6000 & 2.06559 & 4,267 \\
Valid N (listwise) & 10 & & & & & & \\
China & & & & & & & \\
Index & & & & & & & \\
Not_Disclosed & 10 & 33.33 & 63.89 & 544.44 & 54.4444 & 9.09106 & 82647 \\
Narrative_Disc & 10 & $13: 00$ & 24.00 & 164.00 & 16.4000 & 3.27278 & 10711 \\
Numeric_Disc & 10 & $6: 00$ & $21: 00$ & 120.00 & 12.0000 & 5.29150 & 28,000 \\
Currency_Disc & 10 & $1: 00$ & $15: 00$ & 73.00 & 7.3000 & 5.20790 & 27122 \\
Graphics_Disc & 10 & .00 & .00 & .00 & .0000 & .00000 & .000 \\
Valid N (listwise) & 10 & .00 & $2: 00$ & $3: 00$ & .3000 & .67495 & .456 \\
& 10 & & & & & & \\
\hline
\end{tabular}


Based on the disclosure table shows the IC among the best universities in Indonesia and China have the same relative value although there are differences but not too significant and relatively small percentage difference. At best University in Indonesia by not revealing as much as $16.8 \%$ of IC, IC is expressed in the form of a narrative of $13.3 \%$, in the form of a figure of $4.3 \%, 0 \%$ and monetary disclosures in the form of a graph of $1.6 \%$. While the disclosure of the IC at the best universities in China amounted to $16.4 \%$ did not disclose IC, IC $12 \%$ disclosure in narrative form, $7.3 \%$ in the form of numbers, $0 \%$ in monetary terms, and by $0.3 \%$ disclosures in graphical form.

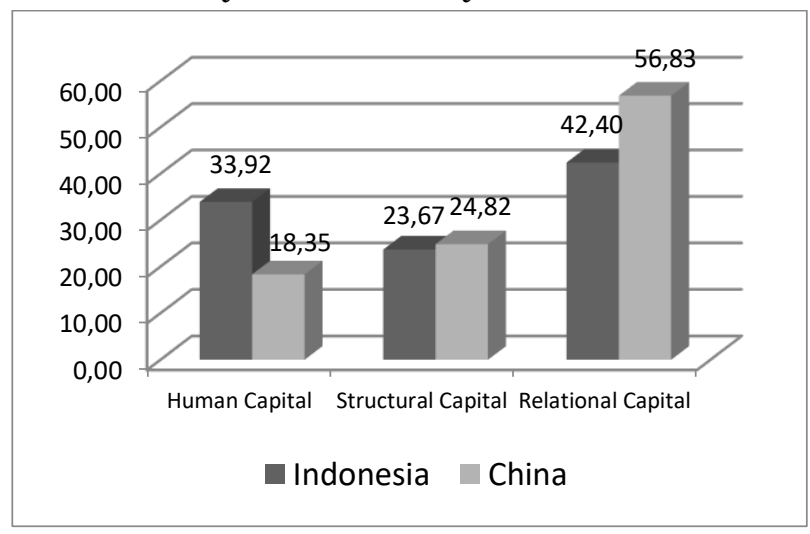

Figure 1. Percentage of intellectual capital disclosure by the best Indonesia and China universities

Figure 1 shows that the percentage of disclosure of Intellectual Capital (IC) at universities in Indonesia and China are relatively similar. Indonesia excels in Human Capital category, while China excels in the number of disclosures Intellectual Capital (IC) for category Capital Structural and Relational Capital. But the difference between them is quite significant in the category of Human Capital and Relational Capital. In general, the disclosure of IC by the best universities in Indonesia has been quite good. This is evidenced by the six universities that revealed more than $50 \%$ of items IC and four other universities present information of less than 50\%. Meanwhile, with the best universities in China that reveal IC more than $50 \%$ as much as seven universities, while three other universities present information of less than $50 \%$.

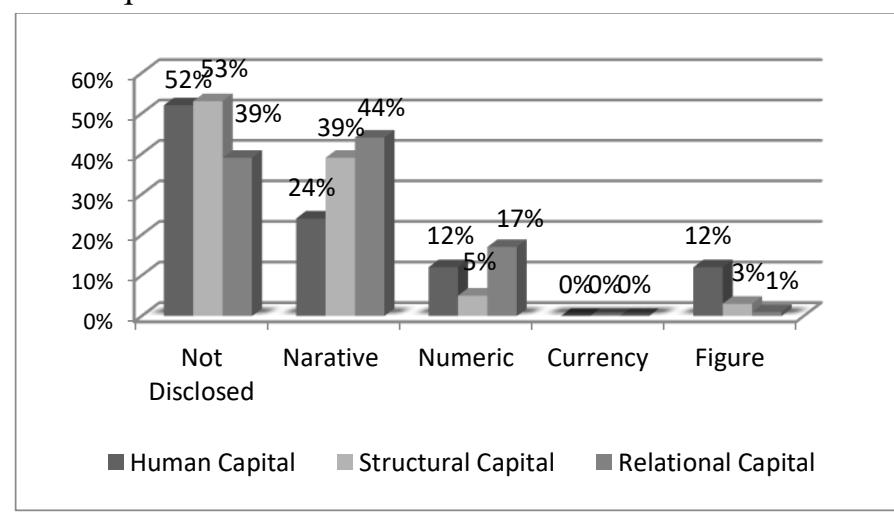

Figure 2. Percentage of Disclosure IC 10 Best University in Indonesia 
From figure 2 shows that the percentage of disclosure of information on the items Human Capital on the 10 best universities in Indonesia, more is presented in a narrative form as much as $24 \%$ to as much as $12 \%$ numeric, and graphics/images as much as $12 \%$. While the disclosure of information on the items Relational Capital on the 10 best universities in Indonesia, more is presented in a narrative form as much as $44 \%$ to as much as $17 \%$ numeric and graphic / picture is only $1 \%$. Ten of the best universities in Indonesia did not disclose the monetary IC as in the website more express in narrative form, and only a few universities that perform such numerical disclosures IC with Gadjah Mada University and the University of Indonesia. Structural Capital more items were not disclosed by $53 \%$,

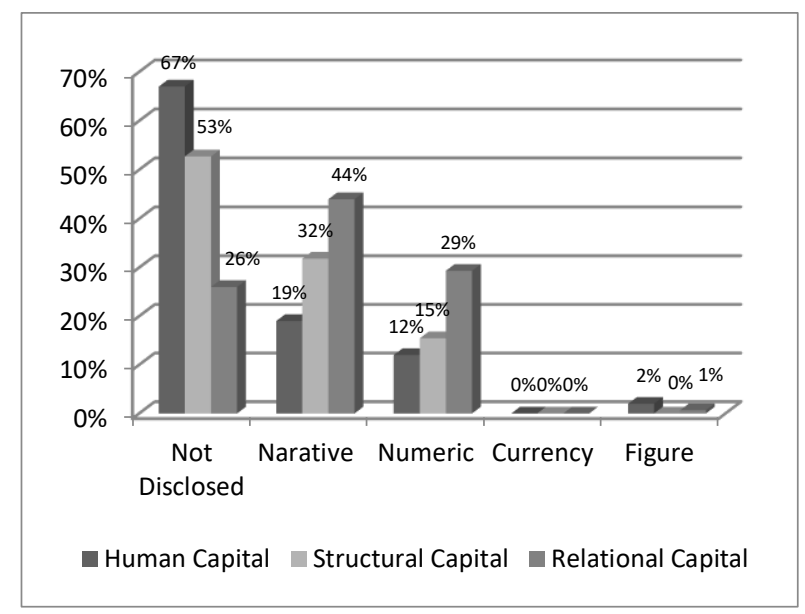

Figure 3. Percentage of Disclosure IC 10 Best Universities in China

Of figure 3 shows that the percentage of the disclosure of the IC in the 10 best universities of China presents information IC almost the same with the presentation of information on universities in Indonesia, namely regarding the item Structural Capital is expressed in narrative form as much as $44 \%$, the disclosure in the form of numeric much as $29 \%$ and the image/chart is only $1 \%$ of. Item Relational Capital also revealed more in narrative form as much as $32 \%$, in the form of a numeric expression as much as $15 \%$, while the disclosure in the form of pictures/graphics only $0 \%$. In this case, the item more human capital is not disclosed by $67 \%$, while the relational capital items not disclosed only by $26 \%$. For IC disclosure in monetary form,

\section{Mann-Whitney Test}

Table 1 illustrates the average disclosure IC at the best universities in Indonesia is greater when compared with the best universities in China according to the survey 4 International Colleges and Universities (4ICU) 2018. This is evidenced by the average number of disclosure of intellectual capital at universities in Indonesia for 10.85 or $52 \%$, while the average disclosure of intellectual capital at universities in China amounted to 10.15 or $48 \%$. 
Table 3. Test Results Mean

\begin{tabular}{lllrr}
\hline & University & $\mathrm{N}$ & mean Rank & Sum of Ranks \\
\hline IC & Indonesia & 10 & 10.85 & 108.50 \\
& China & 10 & $10: 15$ & 101.50 \\
& Total & 20 & & \\
\hline
\end{tabular}

In this test, the Mann-Whitney test was used to compare the number of votes of intellectual capital among the best universities in Indonesia and the best universities in China according to the survey 4 International Colleges and Universities (4ICU) 2018. The Mann-Whitney test is one of the non-parametric tests were very strong and an alternative test of parametric test t-test.

Table 4. Results of Mann-Whitney Test Statistics

\begin{tabular}{lr|}
\hline & IC \\
Mann-Whitney & U46.500 \\
Wilcoxon W & 101,500 \\
Z & -.266 \\
Asymp. Sig. (2-tailed) & .790 \\
Exact Sig. [2 * (1-tailed Sig.)] & $.796 \mathrm{a}$ \\
\hline
\end{tabular}

Table 2 shows that the value of $Z$ count is -0.266. Asymp value. Sig. (2-tailed) in this study is 0.790 , so it can be said that the disclosure of the IC on the official website among the best universities in Indonesia and the best universities in China is not a significant difference, said there is no significant difference seen from Asymp value. Sig. (2-tailed) in this study $>0.05$ is equal to 0.790 , while it can be said the difference if the value Asymp. Sig. (2-tailed) <0.50.

The absence of differences of Mann-Whitney test results is due to the disclosure of intellectual capital in Indonesia's best universities and the best universities in China are relatively the same, although there are differences but not too significant and relatively small percentage difference. Differences disclosure of intellectual capital in the best universities in Indonesia and the best universities in China averaged in the form of disclosure of the item is a lecturer and graduation (graduates), has many of the best universities in Indonesia reveal the number of lecturers and graduation (graduates) in the form of graphics/ pictures, while the best universities in China only reveal the item number of lecturers and graduation (graduates) in the form of narrative and numerical.

Indonesia's best universities and the best universities in China have awareness of the importance of the publication of the university's activities and disclosure of information via the website, it proves that the university has a good public openness to the public and stakeholders. The goal of the university's website is to inform the outside world, namely the public about the academic information, research, and dedication, as well as general information about the university (Ulum et al. 2016). The website is the most popular medium so that the best universities in Indonesia and the best universities 
in China more actively in updating the website owned with the aim to increase bargaining power for the university.

Public Information Openness (KIP) has been set in Law of the Republic of Indonesia Number 14 the Year 2018, In such cases were referred to public information is the information generated, stored, managed, delivered and accepted by the public body pertaining to the organizers and the implementation of state or public agencies relating to the public interest (Ulum et al. 2016). Public body in question, namely the executive, legislative, judicial, and other entities associated with the main task of state and nongovernmental organizations are wholly or partly funded from the budget, community contributions, and abroad (Ulum et al. 2016). With the existence of UU KIP claimed to be a more open university because the university is under the management of the country, so that performance is monitored state university. Based on these descriptions indicate if disclosure of the items IC at the best universities in Indonesia and the best universities in China is not a significant difference. In a content analysis is average difference between the total value disclosures caused by differences in disclosure forms, most of the university were present disclosure in the form of graphs and numerical so the value is higher, whereas other universities only reveal the narrative even do not reveal that the value assigned relatively lower,

\section{CONCLUSION}

The result showed that the disclosure of the IC at the best universities in Indonesia highest disclosed by the University of Indonesia with a total rating of $66 \%$, while the lowest IC disclosure is the disclosure of the IC at Bandung Institute of Technology with the number of votes by $33 \%$. IC on the official website disclosure of the best universities in China revealed the highest IC items by 65\% expressed by Wuhan University. While the disclosure of the lowest IC 33\% expressed by Tsinghua University. Another among the best universities in Indonesia and China is already quite a lot of revealing information ICs, but these universities more revealing only in narrative form so that the values given only one, there are very few universities that reveal an item IC in the form of graphics/images or monetary with four and three votes. This has led to the number of votes is still relatively low.

\section{Acknowledgement}

The work is financially supported by the Universities in carrying out scientific research for 2018 .

\section{References}

Bjurstrom, E., and H. Roberts. 2007. The Principle of Connectivity: Networked Assets, Strategic Capabilities and Bundled Outcomes. In Intellectual Capital Revisited, edited by P. i. t. K. Organization. Cheltenha: Edgar Elgar.

Bollen, L., P. Vergauwen, and S. Schnieders. 2005. Linking intellectual capital and intellectual property to company performance. Management Decision 43 (9):11611185 . 
Bonavia, D. 1999. Cina dan Masyarakatnya. Jakarta: Erlangga.

Bontis, N. 1998. Intellectual capital: an exploratory study that develops measures and models. Management Decision 32 (6):63-76.

Bontis, N., W. C. C. Keow, and S. Richardson. 2000. Intellectual capital and business performance in Malaysian industries. Journal of Intellectual Capital 1 (1):85-100.

Cahyuni, I., I. Ulum, and A. Prasetyo. 2012. Analisis Pengungkapan Intellectual Capital pada Official Website Peraih Qs Star di Indonesia 2011; Komparasi Antara Perguruan Tinggi Negeri (PTN) dan Swasta (PTS). In Simposium Nasional Akuntansi ङ Bisnis. Bandung.

Canibano, L., and M. P. Sanchez. 2009. Intangibles in universities: current challenges for measuring and reporting. Journal of Human Resource Costing $\&^{2}$ Accounting 13 (2):93-104.

Chang, S.-C., S.-S. Chen, and J.-H. Lai. 2008. The effect of alliance experience and intellectual capital on the value creation of international strategic alliances. International Journal of Management Science 36 (2):298-316.

Chen, I., and J. Chen. 2018. Present and future: A trend forecasting and ranking of university types for innovative development from an intellectual capital perspective. Quality and Quantity 47 (1):335-352.

Childs, R. D. 2018. An information age university: a living organism based on Intellectual capital 2011 [cited 01 Juni 2018]. Available from http://www.ndu.edu/irmc/publications/childs3.htm

Commission Europe. 2006. The Commission Of The European Communities.

Constantin. 2005. The intellectual capital of universities. Academy of Economic Studies: Bucharest.

Constantin, B. 2007. The Intellectual Capital of Universities. Academy of Economic Studies.

Deegan, C. 2014. Financial Accounting Theory. Sydney: McGraw-Hill Book Company.

Ghozali, I. 2006. Statistik non-parametrik: Teori dan aplikasi dengan program SPSS. Semarang: Universitas Diponegoro.

Indonesian Government Regulation Number 24 of 1997. Pendaftaran Tanah.

Indonesian Government Regulation Number 43 of 2008. Air tanah.

Jones, N., C. Meadow, and M.-A. Sicilia. 2009. Measuring Intellectual Capital in Higher Education. Journal of Information $\mathcal{E}^{2}$ Knowledge Management 8 (2):113-136.

Law of the Republic of Indonesia Number 14 the Year 2018. Public Information.

Leitner, K.-H. 2002. Intellectual Capital Reporting for Universities: Conceptual background and application within the reorganisation of Austrian universities. In The Transparent Enterprise. The Value of Intangibles. Madrid, Spain: Autonomous University of Madrid.

2004. Intellectual capital reporting for universities conceptual background and application for Austrian universities. Research Evaluation 13 (2):129-140.

Lu, W.-M. 2012. Intellectual capital and university performance in Taiwan. Economic Modelling 29:1081-1089. 
Martinez-Torres, R. 2006. A procedure to design a structural and measurement model of Intellectual Capital: An exploratory study. Information \& Management 43 (5):617-626.

Marzo, G. 2014. Improving internal consistency in IC research and practice: IC and the theory of the firm. Journal of Intellectual Capital 15 (1):38-64.

Najim, N. A., M. A. Al-Naimi, and L. Alnaji. 2012. Impact of Intellectual Capital on Realizing University Goals in a Sample of Jordanian Universities. European Journal of Business and Management 4 (14).

Orleans, L. A. 1960. Professional Manpower and Education in Communist China, Washington, National Science Foundation.111.

Pribac, L.-I. 2010. Intellectual Investment. The Prospects In Education In The USA And In The Eu. Annals of the University of Petroşani, Economics 10 (1):279-288.

Puspitahati, A., I. Ulum, and A. Prasetyo. 2011. Analisis Pengungkapan Intellectual Capital pada Website Tiga Perguruan Tinggi di Indonesia. Paper read at Proceeding Seminar Nasional \& Call for Paper, 19 Februari 2011, at FE Universitas Muhammadiyah Sidoarjo.

Ramírez, Y., C. Lorduy, and J. A. Rojas. 2007. Intellectual capital management in Spanish universities. Journal of Intellectual Capital 8 (4):732-748.

Robert. 1999. The Control of Intangibles in the Knowledge-Intensive Firm. In Communication presented at 22th Annual Congress European Accounting Association. Burdox.

Sanchez, M. P., S. Elena, and R. Castrillo. 2006. Intellectual capital in universities. Journal of Intellectual Capital 7 (4):529-548.

-2009. Intellectual capital dynamics in universities: a reporting model. Journal of Intellectual Capital 10 (2):307-324.

Steward, T. A. 1997. Intellectual Capital: The New Wealth of Organizations. Fortune.

Suciu, M.-C., I.-V. Dragulanescu, and A. Ghitiu-Bratescu. 2011. Universities' Role In Knowledge-Based Economy And Society Implications For Romanian Economics Higher Education. Amfiteatru Economic 8 (30):420-436.

Sugianto, E. I., and A. Trilaksana. 2015. Universitas Terbuka di Indonesia Tahun 19841994. e-Journal Pendidikan Sejarah 3 (2).

Supomo, B., and N. Indriantoro. 2002. Metodologi Penelitian Bisnis. Yogyakarta: BPFE UGM.

Tan, H. P., D. Plowman, and P. Hancock. 2007. Intellectual capital and financial returns of companies. Journal of Intellectual Capital 8 (1):76-95.

Tung, M. T. 2001. Empat Karya Filsafat. Yogyakarta: FuSPAD.

Ulum, I., and A. Juanda. 2016. Metodologi Penelitian Akuntansi. Yogyakarta: Aditya Media Publishing.

Ulum, I., A. Tenrisumpala, and E. D. Wahyuni. 2016. Intellectual Capital Disclosure: Studi Komparasi Antara Universitas Di Indonesia Dan Malaysia. Jurnal Ilmu Akuntansi 9 (1): 13 - 26 